\title{
ADVANCE IN GLACIER MODELLING: GIS AND ORIENTED PROGRAMMING APPROACH APPLIED ON WHITTIER GLACIER, ALASKA
}

\author{
NISTOR, M. M. ${ }^{1{ }^{*} \dagger}-$ DEZSI, Ş. T. ${ }^{2}-$ BEGNARDI, L. ${ }^{3}-$ PRADELLI, M. ${ }^{3}$ \\ ${ }^{1}$ Department of Chemical and Geological Sciences, University of Modena and Reggio Emilia, \\ Campi Street, No. 103, 41125, Modena, Italy \\ ${ }^{\dagger}$ Current affiliation: Nanyang Technological University, School of Civil \\ Environmental Engineering, 42 Nanyang Avenue, Singapore \\ ${ }^{2}$ Faculty of Geography, University of "Babeş-Bolyai", Clinicilor Street, No. 5-7, 400006, Cluj- \\ Napoca, Romania \\ ${ }^{3}$ Department of Engineering "Enzo Ferrari”, University of Modena and Reggio Emilia, Pietro \\ Vivarelli Street, No. 10, Int. 1, 41125, Modena, Italy \\ *Corresponding author \\ e-mail:renddel@yahoo.com \\ (Received $4^{\text {th }}$ Mar 2016; accepted $28^{\text {th }}$ Jan 2017)
}

\begin{abstract}
The global warming affects drastically the glaciers melting, a fact for which the glaciers from Alaska are continuously retreating. Based on Geographical Information System and oriented programming, we have defined a new method to model the glaciers. The Whittier Glacier from South Alaska was analysed in the last 30 years and it was modelled under climate conditions of the $21^{\text {st }}$ century. The glacier modelling has come out from calculations of annual retreat rate, the hemisphere, the latitude, the annual temperature, the precipitation, the altitude data, and the aspect of flow direction. The prediction model of Whittier Glacier shows a value of $1.0544 \mathrm{~km}^{2}$ of losing ice area up to year 2030, a value of $2.2184 \mathrm{~km}^{2}$ of retreat area up to 2050 , a value of $3.9704 \mathrm{~km}^{2}$ up to 2080 , and a value of 5.1524 $\mathrm{km}^{2}$ up to 2100 . We estimate a total loss ice volume related to this melting area of $0.3393 \mathrm{~km}^{3}$. The future scenario indicates a glacier volume reduction of $84.89 \%$ up to 2050 . These findings are useful for glaciologists, but also the paper contributes to Alaskan glaciers knowledge.
\end{abstract}

Keywords: climate change, satellite images, ice retreat, prediction model, melting

Abbreviations

GIS - Geographical Information Systems

asl - above sea level

$\mathrm{Rr}$ - retreat coefficient

\section{Introduction}

Scientists use models for future predictions of different entities like climate, water resources or ecosystems. The environmental systems are continuously changing and consequently, human safety, in term of habitat and the real conditions of life, depends not only on atrophic systems but imply the global changes too. Climate change drastically affects groundwater and food resources and indirectly the coastal shore habitats in ice land masses' proximity.

In the Earth Science expertise area, many scientists have agreed with the models to see how to evolve the systems for future periods in hydrogeology, chemistry, volcanology, and seismology. IPCC (2007) claimed the global climate changes and up 
to $3{ }^{\circ} \mathrm{C}$ temperature change was predicted for the current century. The Alaskan glacier behavior observed shows that not all glaciers melt due to climate warming, some registered_retreat due to landslides, eruptions, and surge dynamics (Molnia, 2006). The ocean branches penetrate into presents Prince William Sound fjords and the local climate became more humid during the summers. This thing accelerates the water flow rate in surface glacier crevices, a fact for which the glaciers located near the shore are more affected by regression. The snowfall during the cold seasons and precipitation quantity during the summers contribute to the glacier mass balance.

Here we present an Alaskan glacier model constructed for present century, which predicts the retreat rate of Whittier Glacier for different years up to 2100 . We realized the glacier modelling using object-oriented programming and Geographical Information Systems (GIS). The program base was a preliminary study of Whittier Glacier through field research and drawing the outlines based on satellite images dated from 1973 to 2013. Taking into account the field's characteristics, local climate data, and a retreat rate along almost 40 years, a conceptual model formed by five classes in Eclipse software from Java platform was projected. Considering the past and recent physical characteristics of Whittier Glacier it was easy to calibrate the model closed to actual climatic conditions.

Many studies about climate (Oerlemans, 1994; Collins, 2008; Piao et al., 2010), water or landslides define firstly a conceptual model and further, the researches researchers start the modelling with the software. The regression of glaciers from the world is very complicated. The equilibrium between ice mass movements is difficult to generalize because each glacier was formed in a proper morphological condition, has proper slope aspect and its flow directions, and slip on itself-pattern. The surface rivers have a basic level in each cycle that could be a bigger river, a lake, sea or ocean, but the glacier pressure on the ground is not related to a base level. In Passage Canal were demonstrated that three glaciers situated close to each other had various retreat rates in the same period and under the same climatic conditions (Nistor and Petcu, 2015). In the ablation area of one glacier, many factors involved. For example, if the annual temperature is a positive and precipitation quantity is higher than heat energy, the glacier could easily retreat. On the other hand, if the annual precipitation such as snow is connected with low annual temperature, the glacier could be stable from area and volume point of view. Moreover, as the climate is warming some glaciers from Caucasus extends the tongue due to ice plasticity. The field characteristics and glacier thickness represent other factors that contribute to glacier behaviour. The geomorphological processes of side slopes and decompression forces of glacial wall's valley conduct at landslides and rock falls from lateral scree. Usually, the rock fall blocks have a dark colour in contrast with glacier brightness, a fact which implies higher heat energy of landslides and rock fall. Thus, in these sector of glaciers, the melting rate is greater.

The main objective of the present paper is to construct a model of the Whittier Glacier up to 2100. The glacier modelling is based on the past and future projections of climate data and it is based also on the GIS applications and satellite images. The GIS techniques and satellite images contribute to determining the annual retreat rate of Whittier Glacier and to draw the future glacier outlines. 


\section{Materials and methods}

\section{Alaskan glaciers shifts and Whittier Glacier}

The glaciers from Alaska were studied by the United States Geological Survey (USGS) and in the last 50 years, various retreat rates were found. Mayo et al. (1977), Kennedy et al. (2006) reconstructed the Portage Glacier terminus status starting in 1914. Portage Glacier is located near Whittier Glacier and the terminus limits predicted in 2020 was exceeded in 2009 (Nistor and Petcu, 2014). Nistor and Petcu (2015) completed a quantitative analysis of three glaciers from Passage Canal in the last decades. They found a continuous annual retreat rate which varies from $0.025 \mathrm{~km}^{2} \mathrm{yr}^{-1}$ to $0.083 \mathrm{~km}^{2} \mathrm{yr}^{-1}$. This is a tragic result regarding the Whittier Creek flooding system discharge and the Whittier town harbour activity (Nistor, 2013).

Whittier Glacier is located in Passage Canal Fjord from Prince William Sound, on the northern Kenai Peninsula. The Passage Canal Fjord has Dfc climate, characterized by fully humid and cool summer, in which the evapotranspiration has lower values.

Whittier Glacier (Figure 1) is an outlet glacier flowing from the Harding Ice field, with a small slope and it has flow direction from south-southwest to north-northeast. Whittier Glacier extends in altitude between $470 \mathrm{~m}$ and $1013 \mathrm{~m}$ above sea level (asl), and it presents a large terminus limit, a fact which makes and have various sensitive sites. The Whittier Glacier extends from the south of Whittier town in the Kenai Mountains. From the Landsat satellite images were carried out the limits of Whittier Glacier starting in 1973 to 2014. The oldest data of Whittier Glacier bring forward that in 1910 the terminus of this glacier was only at $1 \mathrm{~km}$ distance to shore (Barnes, 1943). Barnes (1943) recalls in his works that the terminus was shifted between 1913 and 1939
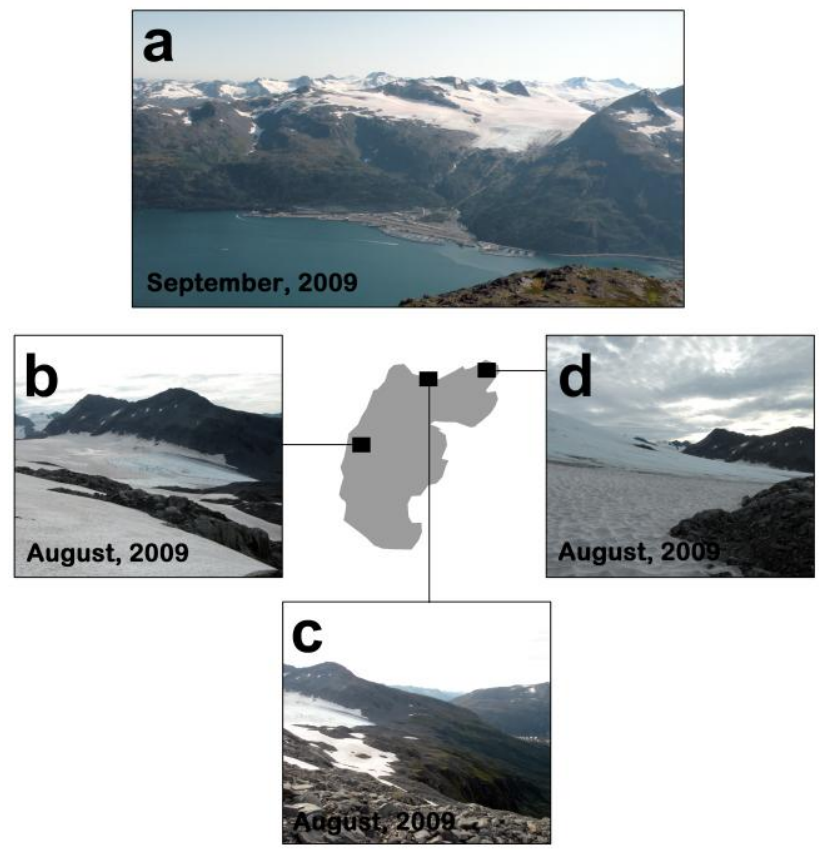

Figure 1. Views with Whittier Glacier. a. Oblique south-looking aerial photograph of Whittier Glacier (September, 2009). b. West-looking ground photograph of central sector of Whittier Glacier (August, 2009).c. Terminus of glacier near the glacial threshold (August, 2009).d. Terminus of glacier in the north-eastern extremity (August, 2009). Photo courtesy: Nistor. 
from $180 \mathrm{~m}$ asl to $300 \mathrm{~m}$ asl. Interestingly, based on GIS and Landsat images the eastern and north-eastern part of the glacier was depicted more sensitive than other parts (Nistor and Petcu, 2015).

\section{Climate data}

The mean annual air temperature, mean annual precipitation, and annual snow depth from 1985 to 2010 was used together with monthly temperature data, precipitation, and snowfall from 1960 to 2010 to assess the climate conditions in which is the major retreat of Whittier Glacier. The climate data used in the calibration belongs to Whittier meteorological stations and are courtesy of Western Regional Climate Center (2014). In the calculations of future climate data parameters the CGCM2 in the GHG+A IS92a models has been adopted (The Canadian Centre for Climate Modelling and Analysis, 2015a; The Canadian Centre for Climate Modelling and Analysis, 2015b) created in transient runs and its relative change plots served into future absolute calculations that are based on meteorological data from Whittier station. It is safe to mention that the Western Regional Climate Center data of temperature and precipitation are expressed in Fahrenheit degrees respectively in Inches and in the present work, the temperature and precipitation data are converted to Celsius and millimetres respectively.

\section{Landsat data}

Whittier Glacier outlines were extracted through remote sensing in one band using GIS and satellite images. Using ArcGIS 10.2 software and optical remote sensing with Landsat satellite images (United States Geological Survey, 2015), the spatial extension of Whittier Glacier was drawn in various set times from 1973 to 2014.

During the last decades, many glaciers and ice lands studies have been made based on satellite images and remote sensing (Echelmeyer et al., 2004; Holobâcă, 2013). Molnia (2008), Kargel et al. (2005) present in their papers the contribution of satellite images in ice land measurements. Nistor and Petcu (2015) carried out the annual retreat rate of Whittier, Learnard, and Billings glaciers from 1985 until 2013, using the Landsat images.

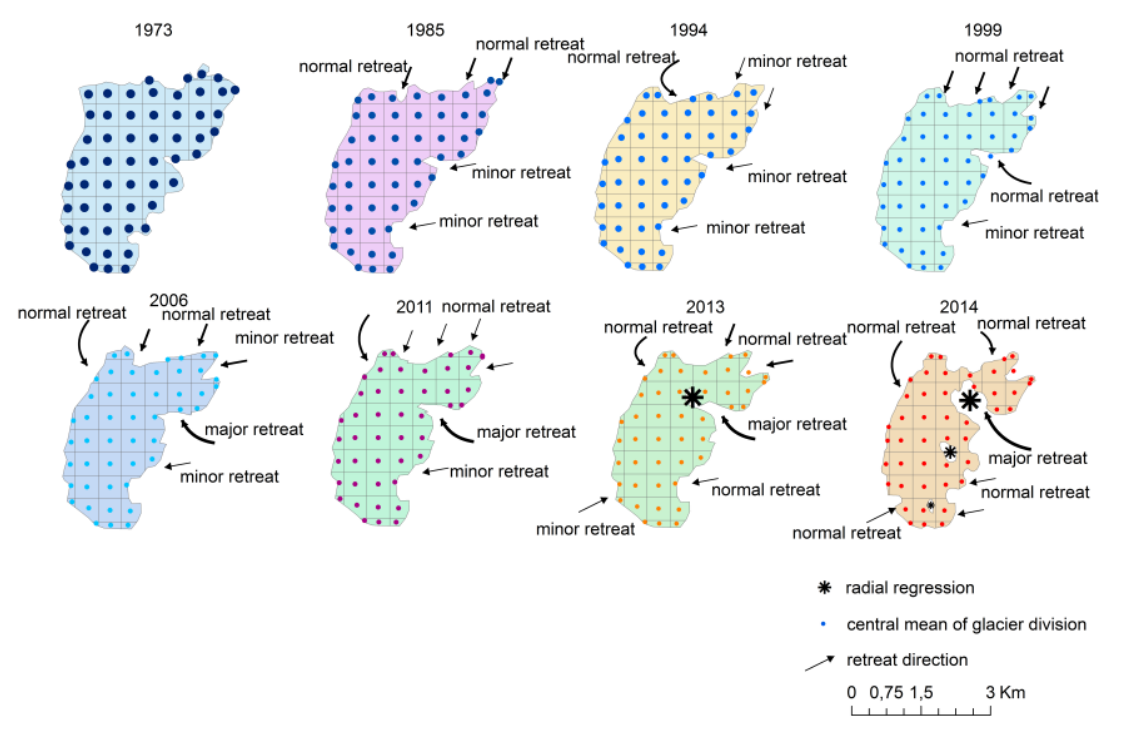

Figure 2. Division in polygons of glacier outlines and founding the sensitive retreat zones using the 'Central mean' analysis. 
To complete this study with the spatial extension of Whittier Glacier in the future, the GIS techniques was linked to results carried out through Java model constructed and calibrated in Eclipse software. This procedure was essential for the glacier modelling because it gives the future perspective of Whittier Glacier and in case of flooding or the Pacific Ocean rise risks the planning precautions could be.

Based on GIS techniques, two innovative methods were combined to delimit the future outlines of Whittier Glacier. Firstly, the vector data of glacier outlines were divided into network quarts of $500 \mathrm{~m}$ dimension through 'Intersect' function. Data Management Tools served to find the centres of these polygons using the 'Make XY Event Layer' function. This spectacular and innovative method was used to identify the terminus retreat directions (Figure 2) for past years and after was taken into consideration for future glacier projections. A 'Central Mean' function was applied and tested to identify the general retreat and sensitive areas of Billings Glacier, Learnard Glacier, and Whittier Glacier by Nistor and Petcu (2015).

Figure 3 depicts the simple steps used in this methodology. Through these methods, the retreat sites of the glacier were found, as soon as the mathematical calculations argue these locations. For the analysis of Whittier Glacier outlines in different set times were used ArcGIS 10.2 software applications and thus we calculated the retreat rates of Whittier Glacier. Digital elevation model, thickness grid, 'Central mean' positions of vector divisions, backed with field researches was considered in the spatial representation of the Whittier Glacier. The outlines of Whittier Glacier were extracted by manual vectorization considering as much as possible the satellite images from autumn or late summer period. Also, for the outlines precision, the local field research observations were done. These things helped to define more clearly the limits of Whittier Glacier.

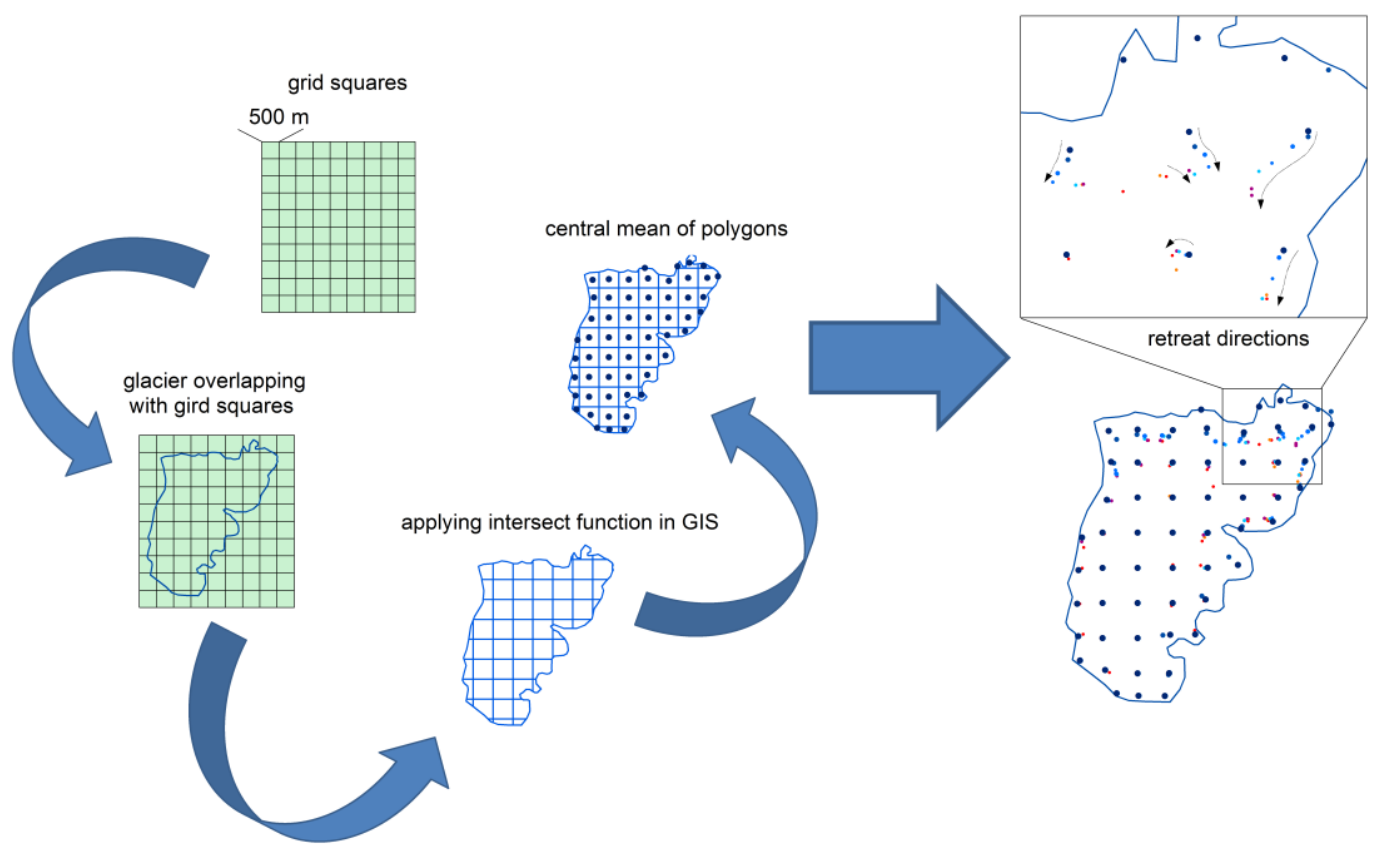

Figure 3. General framework of the 'Central mean' methodology. 


\section{The conceptual model of Whittier Glacier}

Glacier modelling is a complex matter under climate warming, local field's field conditions and processes. The climate data analysis and the calculated retreat rates served to build a conceptual model of Whittier Glacier, which further permits to project the retreat of Whittier Glacier and its extensive area for future periods, up to 2100.

For this reason, this study started with a model that predict the retreat rate of Whittier Glacier under climate change taken into account the temperature and precipitation climate data, the hemisphere glacier location, the glacier latitude, the glacier altitude, and the glacier slope aspect. These data influences are elementary to the ice mass melting. The field research and Whittier Glacier drawing boundaries in different set times helped to understand how evolved the ice melting during the last 40 years and in which conditions the major retreat is. The climate data are taken into account to observe the relationship between the climate parameters and Whittier Glacier retreat.

The Whittier Glacier thickness data grid obtained by Farinotti et al. (2009) and Huss and Farinotti (2012). They applied an algorithm based on volume-area scaling relation for the entire globe's glaciers.

\section{Glacier modelling method using oriented programming objects}

In an aim to understand correctly the Whittier Glacier retreat pattern, this study proposed an advanced glacier model using GIS and oriented programming, transposing the conceptual model of Whittier Glaciers into Java programming language aimed to project its annual retreat rate for the future period.

This program constructed in Eclipse software and contains five classes as follows: (i) "FieldSettings" class, (ii) "ClimateData" class, (iii) "Glacier" class, (iv) "Processes" class, and (v) "WindowManager" class. The glacier modelling based on combination and relationship between the global position of the glacier, field characteristics, and climate data. "FiedSettings" class includes Whittier Glacier field characteristics like aspect and altitude. In the "ClimateData" class the annual mean temperature and precipitation were inserted. In "Glacier" class the hemisphere data, latitude, area, and glacier length were declared. The "Processes" class refers to retreat rate and sensitive areas. The "WindowManager" class contains the main function which leads to the program running. The program returns the calculated retreat rate values of melting area under climate data, global position, and field characteristics which were added when the program was running. The model was calibrated for 1985-2010 set time. Also performed was the Pearson correlation between the measured retreat rates and the simulation retreat rates for the same period.

Table 1. Measured and simulated retreat rate of Whittier Glacier during the 1985-2010 period.

\begin{tabular}{ccc}
\hline Period & Measured annual retreat $\left(\mathrm{km}^{2} \mathrm{yr}^{-1}\right)$ & Simulated annual retreat rate $\left(\mathrm{km}^{2} \mathrm{yr}^{-1}\right)$ \\
\hline $1985-1994$ & 0.06 & 0.07 \\
$1995-1999$ & 0.09 & 0.08 \\
$2000-2006$ & 0.04 & 0.07 \\
$2007-2010$ & 0.07 & 0.07 \\
\hline
\end{tabular}


The Pearson correlation coefficient reaches the value 0.85 and approves the observed agreement between the measurements and estimations. Table 1 shows the measured and simulated retreat rates during 1985-2010.

This study's model returns the annual retreat rate corresponding to the parameters mentioned. The first step is finding the relationship between annual temperature and annual retreat rate for the years from 1985 to 2010. In this relationship the retreat coefficient was introduced ( $\mathrm{Rr}$ ), which is coming from the additional factor product influencing the Whittier Glacier retreat. Thus, the precipitations, the latitude, the aspect, and the altitude was abstracted in the Java programming language, considering at the same time the retreats of Learnard and Billings glaciers, which are located in the same fjord with Whittier Glacier. The Equation 1 was used in the future predictions of Whittier Glacier and this equation may be used for various glaciers from the different places of the world. In the program code, the $\mathrm{Rr}$ was constructed to increase proportionally with set values only if the rainfall, latitude, and altitude decrease and also if the slope aspect of the glacier is changing from 0 to 360 degree. The various coefficients for the Rr factors (Eq. 2) of rainfall, altitude, and altitude were attributed in an aim to homogenize the calculation and to have the class range of these parameters. The model considers also the inverse impact of global position related to the glaciers situated in the Northern hemisphere and to the glaciers situated in the Southern hemisphere.

$$
\text { Annual retreat rate }=0.0076 * T+R r
$$

$\mathrm{T}$ temperature $\left[{ }^{\circ} \mathrm{C}\right]$

$\mathrm{Rr}$ retreat coefficient

$$
R r=R p \times R a \times R e a s
$$

Rp Retreat precipitation coefficient

$\mathrm{Ra}$ Retreat altitude coefficient

Rea Hemisphere-latitude and aspects coefficient (see Eq. (3))

$$
\operatorname{Rea}=\operatorname{Re} \times \operatorname{Ras}
$$

Re Hemisphere-latitude coefficient

Ras Aspect coefficient

\section{Results}

The GIS and Landsat satellite images were used to reconstruct the historical Whittier Glacier outlines (Figure 4). The GIS measurements indicate that the terminus retreat in north-eastern part has a value of $1446.22 \mathrm{~m}$ and in north-western part a value of 520.47 $\mathrm{m}$ during the 1973-2014 periods. This is possible because of the flat form and large extension of the Whittier Glacier, which influence the thickness reduction in the glacier north-eastern sector. The past Whittier Glacier behaviour analysed through satellite images and various retreat rates were carried out in different set times. In 1973, an area of $9.652 \mathrm{~km}^{2}$ was extracted and until 1985 the glacier diminished with $1.092 \mathrm{~km}^{2}$. The Whittier Glacier retreat rates registered in the past four decade values between 0.038 $0.655 \mathrm{~km}^{2} \mathrm{yr}^{-1}$. The most striking retreat was in 2010', when the retreat rate reached the 
maximum value $\left(0.655 \mathrm{~km}^{2} \mathrm{yr}^{-1}\right)$. Climatological data show no significant modifications in temperature trend that are almost constant from 1960 to 2010 (Figure 5) and a value around $5^{\circ} \mathrm{C}$ of annual temperature was calculated for this period. The changes in rainfall trend identified, as to expect from the glacier melting area. Due to the slight decrease of precipitation after the year 2000 and constant temperature above $0{ }^{\circ} \mathrm{C}$, Whittier Glacier shows a continuous retreat from 1973.

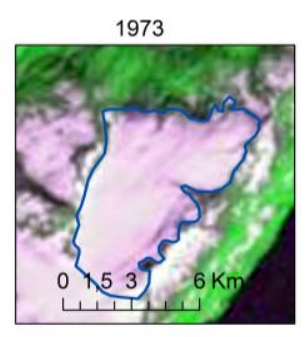

2006

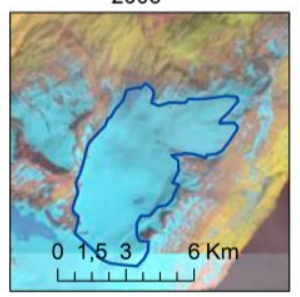

1985

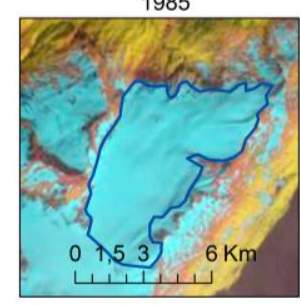

2011

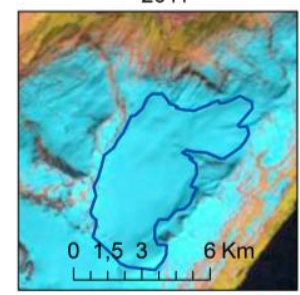

1994

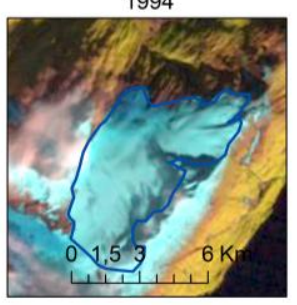

2013

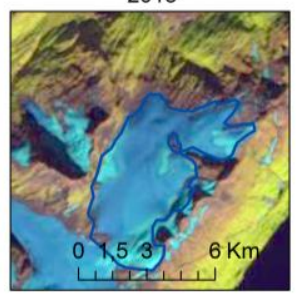

1999

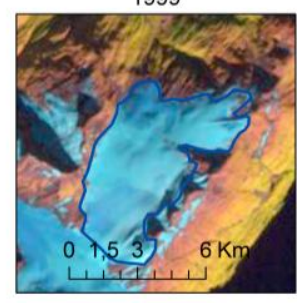

2014

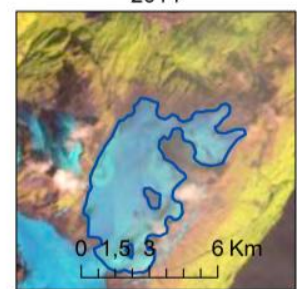

Figure 4. Landsat mosaic images of Whittier Glacier and outlines in 1973, 1985, 1994, 1999, 2006, 2011, 2013 and 2014. Landsat images courtesy of the U.S. Geological Survey.

A correlation between temperature, precipitation, and melting area was important to carry out in estimating the Whittier Glacier future retreat. From the climate data analysis, it was observed that the annual mean temperatures are not changed significantly. The most important changes were identified from the mean annual precipitation in 1986-1995 and 2001-2010 time intervals (Figure 5a). A reduction in precipitation from $5834.63 \mathrm{~mm}$ to $4910.24 \mathrm{~mm}$ were found in the analysis of both set times. These findings are important in the negative balance of Whittier Glacier because even if the temperatures are changed a little (Figure 5b), the glacier cannot be extending more in an area without precipitation and snowfall during the cold seasons. The snow depth ranges from $10 \mathrm{~cm}$ to $85 \mathrm{~cm}$, with a slight decrease after 2000 years (Figure $5 \mathrm{c}$ ). In contrast, if the Whittier Glacier extends because of the high melting rate, the ice volume diminished considerably. On the other hand, from the mean monthly data analysis along 1960-2010 is observed that the precipitation in summer ranged between $267.71 \mathrm{~mm}$ and $371.09 \mathrm{~mm}$ (Figure 6a), while the temperature in summer period exceeded $10{ }^{\circ} \mathrm{C}$ and in July, in August the temperature was higher than $12{ }^{\circ} \mathrm{C}$ (Figure $6 b$ ) and snowfall was $0 \mathrm{~mm}$ (Figure $6 c$ ). This fact drastically influences the glacier retreat because of the water flow action on glacier ice and no accumulation in ice mass.

Starting from the glacier annual retreat data rate and future model climate analysis offered by The Canadian Centre for Climate Modelling and Analysis (2015a) and The Canadian Centre for Climate Modelling and Analysis (2015b), it projected the 
precipitation and temperature data, further used in the glacier modelling. The temperature and precipitation projections for different years up to 2100 are reported in Table 2. Based on the future climate data projections the annual retreat rate and total retreat area of Whittier Glacier were calculated.

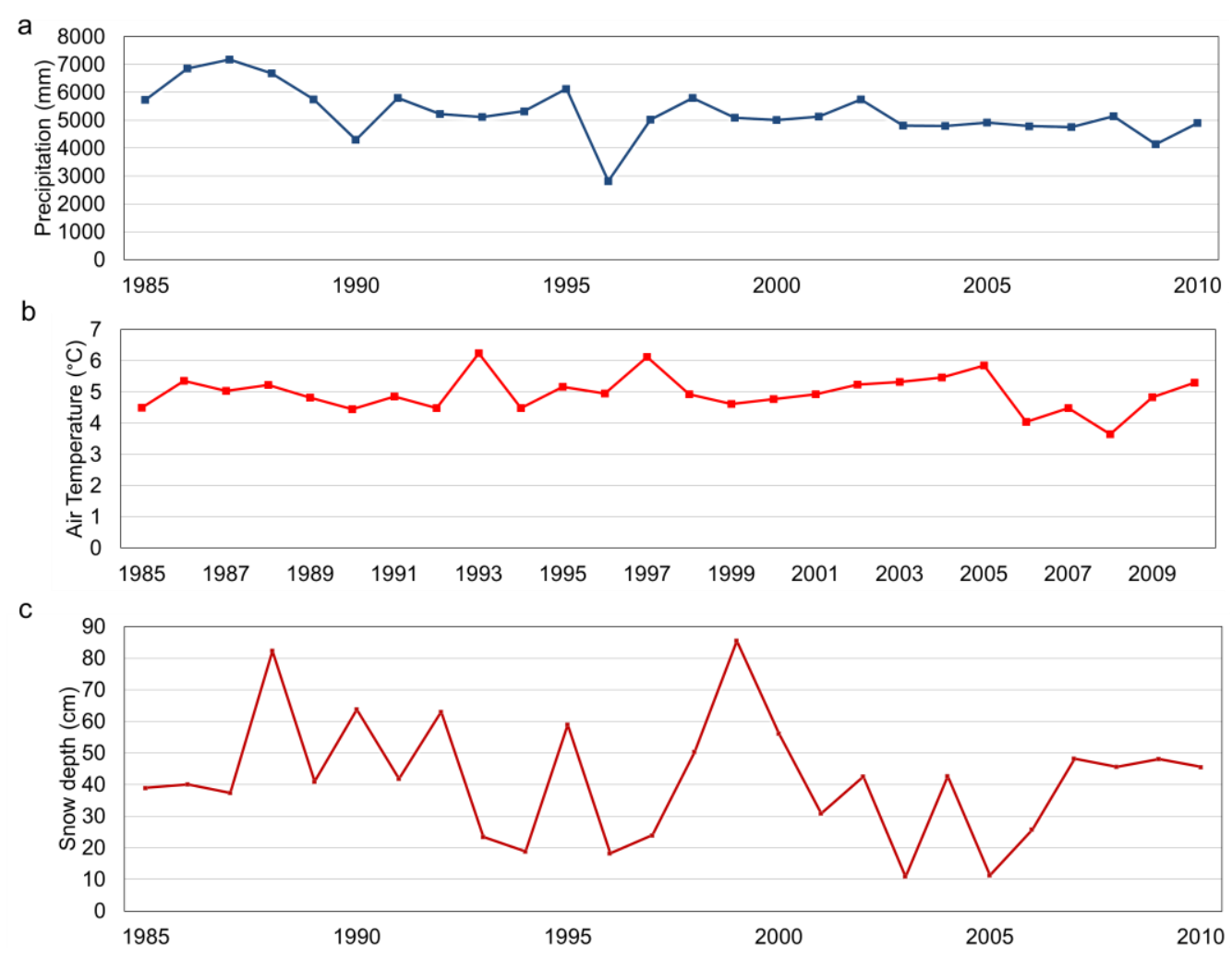

Figure 5. a. Annual mean precipitation measured at Whittier station between 1985-2010. b. Annual mean air temperature measured at Whittier station between 1985-2010. c. Annual mean snow depth measured at Whittier station between 1985-2010. Source: Western Regional Climate Center.

In the future, it was found that a value of the annual retreat rate of $0.065 \mathrm{~km}^{2} \mathrm{yr}-1$ for 2014-2030, a value of $0.058 \mathrm{~km}^{2} \mathrm{yr}-1$ for 2031-2080, and a value of $0.059 \mathrm{~km}^{2} \mathrm{yr}-1$ for 2081-2100 and a total retreat area of $5.1524 \mathrm{~km}^{2}$ is expected to melt by the end of this century.

Table 2. Temperature and precipitation projections for 2030, 2040, 2050, 2080, and 2100.

\begin{tabular}{ccccc}
\hline Year & $\begin{array}{c}\text { Relative change } \\
\left(\mathrm{T}^{\circ} \mathrm{C}\right)\end{array}$ & $\begin{array}{c}\text { Mean temperature } \\
\text { projection }\left({ }^{\circ} \mathrm{C}\right)\end{array}$ & $\begin{array}{c}\text { Relative change } \\
\mathrm{PP}(\mathrm{mm} / \text { year })\end{array}$ & $\begin{array}{c}\text { Mean precipitation } \\
\text { projections (mm/year) }\end{array}$ \\
\hline 2030 & $0,02(+)$ & 4,9317 & $73(+)$ & 5338.692 \\
2040 & $0,03(+)$ & 4,98005 & 0 & 5265.692308 \\
2050 & $0,03(+)$ & 4,98005 & 0 & 5265.692308 \\
2080 & $0,05(+)$ & 5,07675 & 0 & 5265.692308 \\
2100 & $0,06(+)$ & 5,1251 & $91,25(-)$ & 5174.442308 \\
\hline
\end{tabular}


A total melting area of $1.10544 \mathrm{~km} 2$ up to 2030 and $2.2184 \mathrm{~km} 2$ up to 2050 was estimated. This study's model predicts $3.9704 \mathrm{~km} 2$ for 2080 and $5.1524 \mathrm{~km} 2$ for 2100 of total loss area. A volume of $0.3393 \mathrm{~km}^{3}$ will melt between 2014 and 2100 under the present century climate condition. The main spatial melting area for the future was identified in the north, north-eastern, and the eastern part of the Whittier Glacier, while in the southern part the melting area is minor. The high spatial reduction is due to the flattened shape of the Whittier Glacier, with inconsistent thickness. The existing "inselberg" landforms in the glacier slide bed of the Whittier Glacier will contribute to the radial regression of ice mass in the eastern and southern area especially for 2030, 2050, and 2080 outlines projections. Figure 7 highlights the predicted Whittier Glacier outlines for 2030, 2050, 2080, and 2100. For the year 2100 it will be expected that the main ice mass of Whittier Glacier will be in the south-western part compared with the actual position. In Figure 8 are drawn the future outlines of Whittier Glacier on an aerial photograph.
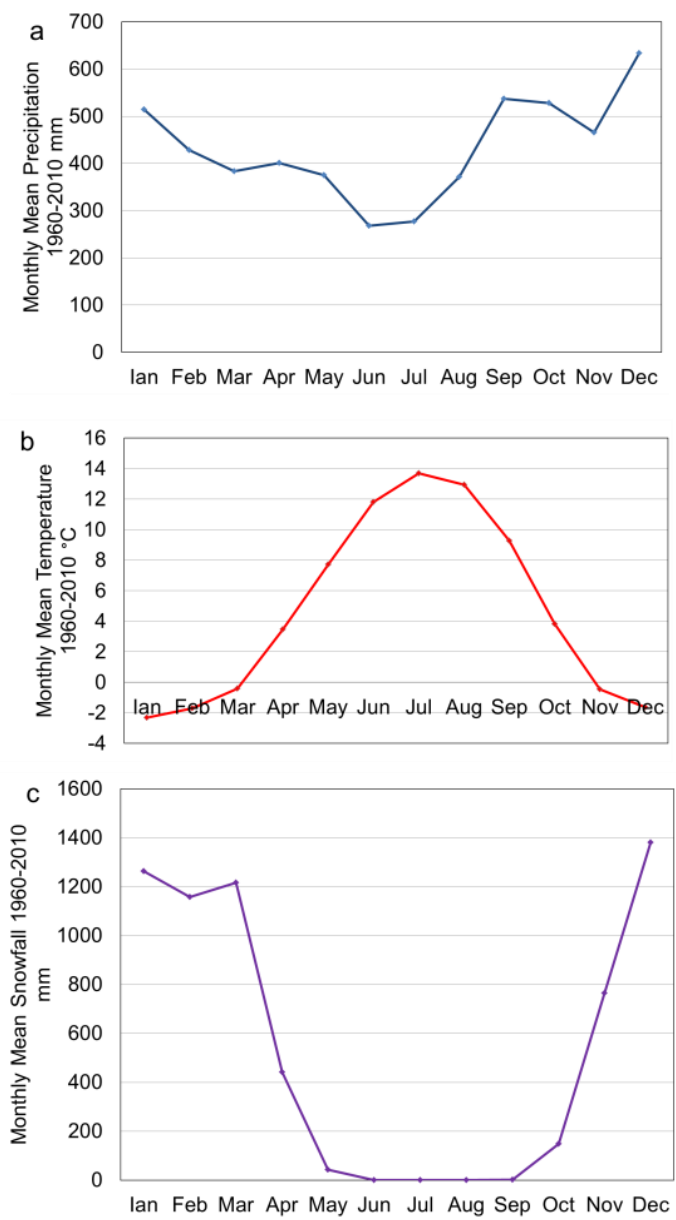

Figure 6. Climatological monthly data between 1960-2010 measured at Whittier station. a. Monthly mean precipitation measured at Whittier station between 1960-2010. b. Monthly mean air temperature measured at Whittier station between 1960-2010. c. Monthly mean snowfall measured at Whittier station between 1960-2010. Source: Western Regional Climate Center. 


\section{Predictions for $\mathbf{2 0 3 0}$ \\ Glacier area rea: $5.0145 \mathrm{~km}^{2}$} Ice volume: $0.3303 \mathrm{~km}^{3}$

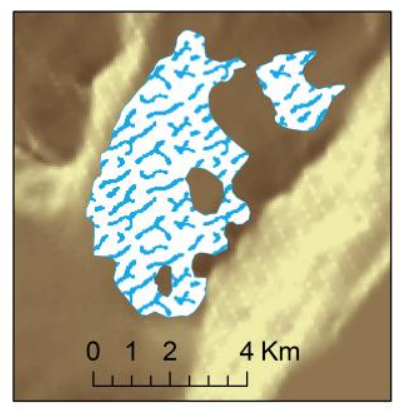

Predictions for $\mathbf{2 0 8 0}$

Glacier area rea: $2.0985 \mathrm{~km}^{2}$ Ice volume: $0.1382 \mathrm{~km}^{3}$

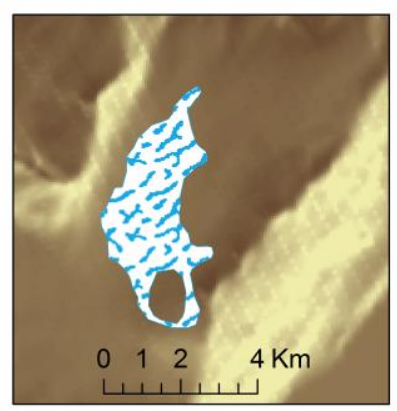

\section{Predictions for $\mathbf{2 0 5 0}$}

Glacier area rea: $3.8505 \mathrm{~km}^{2}$ Ice volume: $0.2536 \mathrm{~km}^{3}$

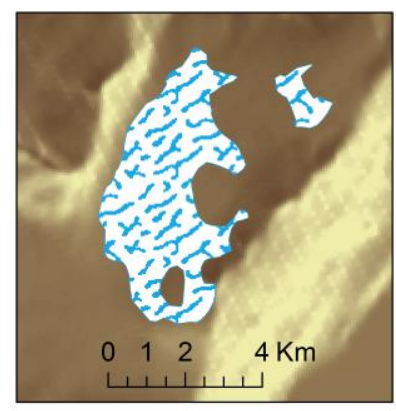

\section{Predictions for $\mathbf{2 1 0 0}$}

Glacier area rea: $0.9165 \mathrm{~km}^{2}$ Ice volume: $0.0604 \mathrm{~km}^{3}$

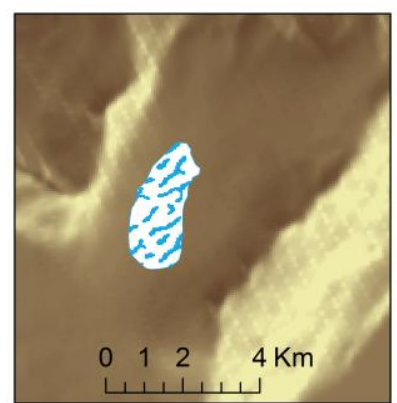

Figure 7. Future projections of the Whittier Glacier outlines for 2030, 2050, 2080 , and 2100.

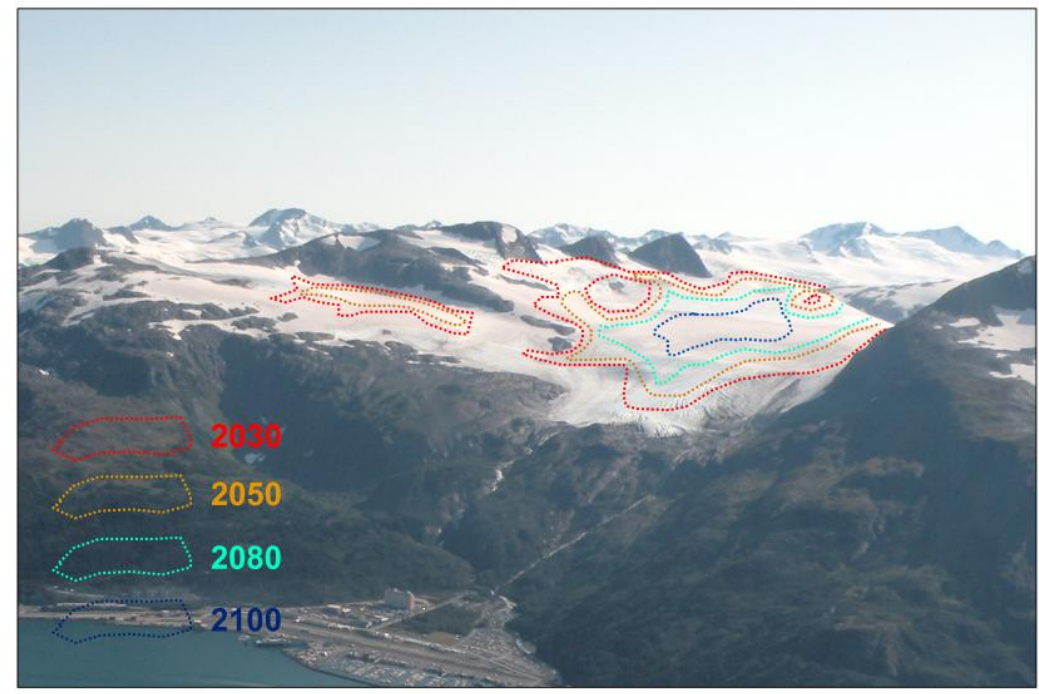

Figure 8. 3D view of Whittier Glacier outlines predictions for 2030, 2050, 2080, and 2100. Photo courtesy: Nistor. 


\section{Discussion and conclusions}

Comparing the results with available climate data from the Whittier meteorological station during the last 40 years, the glacier behaviour under climatic conditions was understood. Based on these findings and field characteristics, the model that will serve future periods was calibrated. The recent global climate changes and continuous warming in the arctic regions results in the ice melting of large areas. Temperatures and precipitations are main climatic data that influences the glacier behaviour. During the last century, many glaciers of the entire world registered high lose areas related to climate warming (Haeberli, 1999; IPCC, 2001; Oerlemans, 2005). Many future scenarios show an increase of 1 to $3{ }^{\circ} \mathrm{C}$ in global temperature trend (IPCC, 2007). For the current century was predicted a rise in temperature and a decrease in precipitation quantity in North America. In addition to climate warming, population growth and its impulsive activity on landscape contribute to glaciers modifications in the $21^{\text {st }}$ century.

Due to climate data temperature projections and precipitation based on models, this study's predictions for future Whittier Glacier outlines and retreat areas have some limitations. In this study, obtaining the Whittier Glacier 3D model is difficult, because of missing hole measurements, but also for more elasticity of ice during hot periods and complex flow glacier movements on the surface roughness of sliding bed. At the same time, the Whittier Glacier spatial retreat area shows the general tendency of future outlines, a fact for which this study's projections did not indicate the top glacier surface.

In contrast, this study's model strait is that the method integrates both glacier field characteristics and the Whittier station climate data. Moreover, this study's methodology for glacier modelling could be applied to other glaciers without loss in performance. The oriented object program was implemented in Java Eclipse to predict the glacier retreat rate related to the Whittier Glacier under geographical position, climate conditions, and field characteristics. The past outlines of Whittier Glacier changes were delineated using satellite images and GIS applications. A new method was proposed to estimate the sensitive melting area and major retreat areas through 'Central Mean' of squares networks applied on vector data outlines of the glacier.

The first and most important conclusion carried out in this study is the Whittier Glacier's drastic reduction in the 21st century. From this finding it would seem that a high discharge of the Whittier Creek and other streams threatens the Whittier town by possible flooding and erosion. Moreover, the marine biomes and the salmon prohibition of Passage Canal could be seriously affected by heating the water in this fjord. Considering the Whittier Glacier's characteristics and local meteorological data conditions, the present paper aims to contribute to glacier modelling based on GIS and Java programming. This model was calibrated to the Whittier Glacier and adapted for use in any of the world's glaciers.

Acknowledgements. We want to express sincere gratitude to Assoc. Prof. Bogdan Enescu for the review of the paper and his suggestions that improved the manuscript. Many thanks are coming also to Alex Berni for supporting in figures editing, but also to the COGNOSCENTI PROOFREADING Org. for the English corrections. We would also like to thank Western Regional Climate for climate data and we thank to U.S. Consulate from Bucharest for the visas support in 2009 and 2010, that were indispensable for the field research. We mention also that Ştefan Dezsi's contributions for this paper are the same like the first and corresponding author. 


\section{REFERENCES}

[1] Barnes, F.F. (1943): Geology of the Portage Pass area, Alaska. United States Geological Survey Bulletin. - Government Printing Office Washington 926D: 211-235.

[2] Collins, D.N. (2008): Climatic warming, glacier recession and runoff from Alpine basins after the Little Ice Age maximum. - Annals of Glaciology 48(1): 119-124.

[3] Echelmeyer, K.A., Valentine, V.B., Zirnheld, S.L. (2004): Airborne surface profiling of Alaskan glaciers. - Boulder Colorado USA: National Snow and Ice Data Center.

[4] Farinotti, D., Huss, M., Bauder, A., Funk, M. (2009): An estimate of the glacier ice volume in the Swiss Alps. - Global and Planetary Change 68: 225-231.

[5] Haeberli, W.R., Frauenfelder, R., Hoelzle, M., Maisch, M. (1999): On rates and acceleration trends of global glacier mass changes. - Physical Geography 81A: 585-595.

[6] Holobâcă, I.H. (2013): Glacier Mapper - a new method designed to assess change in mountain glaciers. - International Journal of Remote Sensing 34(23): 8475-8490.

[7] Huss, M., Farinotti, D. (2012): Distributed ice thickness and volume of all glaciers around the globe. - J. Geophys. Res. 117(F04010), doi:10.1029/2012JF002523.

[8] IPCC. (2007): Climate Change 2007: Impacts, Adaptation and Vulnerability. Contribution of Working Group II to the Fourth Assessment Report of the Intergovernmental Panel on Climate Change, Parry M L, Canziani O F, Palutikof J P, van der Linden P J and Hanson CE eds. Cambridge University Press, Cambridge, UK, 976 pp.

[9] Kargel, J.S., Abrams, M.J., Bishop, M.P., Bush, A., Hamilton, G., Jiskoot, H., Kääb, A., Kieffer, H.H., Lee, E.M., Paul, F., Rau, F., Raup, B., Shroder, J.F., Soltesz, D., Stainforth, S., Stearns, L., Wessels, R. (2005): Multispectral imaging contributions to global land ice measurements from space. - Remote Sensing of Environment 99(1): 187-219.

[10] Kennedy, B.W., Trabant, D.C., Mayo, L.R. (2006): A century of retreat at Portage Glacier, South-Central Alaska. - Anchorage: United States Geological Survey.

[11] Mayo, L.R., Zenone, C., Trabant, D.C. (1977): Reconnaissance hydrology of Portage Glacier basin. - Fairbanks: Department of the interior United States Geological Survey with Unites States Forest Service.

[12] Molnia, B.F. (2006): Late nineteenth to early twenty-first century behavior of Alaskan glaciers as indicators of changing regional climate. - Global and Planetary Change 56: 23-56.

[13] Molnia, B.F. (2008): Satellite image atlas of glaciers of the world, Alaska. United States Geological Survey Professional Paper 1386-K. - Government Printing Office Washington.

[14] Nistor, M.M. (2013): Geological and Geomorphological Features of Kenai and Chugach Mountains in Whittier Area, Alaska. - Studia UBB Geographia, 58: 27-34.

[15] Nistor, M.M., Petcu, I.M. (2015): Quantitative analysis of glaciers changes from Passage Canal based on GIS and satellite images, South Alaska. - Applied Ecology and Environmental Research 13(2): 535-549.

[16] Oerlemans, J. (1994): Quantifying global warming from the retreat of glaciers. - Science 264: 243-245.

[17] Oerlemans, J. (2005): Extracting a Climate Signal from 169 Glacier Records. - Science 308: 675-677.

[18] Piao, S., Ciais, P., Huang, Y., Shen, Z., Peng, S., Li, J., Zhou, L., Liu, H., Ma, Y., Ding, Y., Friedlingstein, P., Liu, C., Tan, K., Yu, Y., Zhang, T., Fang, J. (2010): The impacts of climate change on water resources and agriculture in China. - Nature 467(7311): 43-51.

[19] The Canadian Centre for Climate Modelling and Analysis. (2015a): Projected change in 5-year mean surface air temperature $\left({ }^{\circ} \mathrm{C}\right)$ relative to $1971-90$ as simulated by CGCM2 in the GHG+A IS92a transient runs. URL (Accessed on 21 March 2015): 
http://www.cccma.ec.gc.ca/diagnostics/cgcm2/animation_st_na.shtml.

[20] The Canadian Centre for Climate Modelling and Analysis. (2015b): Projected change in 5-year mean precipitation (mm/day) relative to 1971-90 as simulated by CGCM2 in the GHG+A IS92a transient runs. URL (Accessed on 21 March 2015):

http://www.cccma.ec.gc.ca/diagnostics/cgem2/animation_pcp_na.shtml.

[21] United States Geological Survey. (2015): LandsatLook Images. URL (Accessed on 3 March 2015): http://landsatlook.usgs.gov/.

[22] Western Regional Climate Center. (2014): Monthly summary data lister (SOD-TD3200). Temperature 1985-2010, 509829 Whittier Alaska. URL: http://www.wrcc.dri.edu/cgibin/cliMAIN.pl?ak9829. Accessed on 5 March 2014.

\begin{abstract}
APPENDIX
The climate data used in the paper for climatic analysis belongs to "Western Regional Climate Center". Monthly summary data lister (SOD-TD3200) of temperature during the 1985-2010 period at Whittier meteorological station from Alaska can be found using
\end{abstract}

URL: http://www.wrcc.dri.edu/cgi-bin/cliMAIN.pl?ak9829.

The future projections of climate were done based on climate models carried out by "The Canadian Centre for Climate Modelling and Analysis". The useful links of these data are:

URL: http://www.cccma.ec.gc.ca/diagnostics/cgcm2/animation_st_na.shtml.

URL: http://www.cccma.ec.gc.ca/diagnostics/cgcm2/animation_pcp_na.shtml.

The Landsat images are courtesy of United States Geological Survey. The satellite images can be found on the LandsatLook Images web site.

URL: http://landsatlook.usgs.gov/.

Photos with Whittier Glacier taken during the field survey. Pictures courtesy by Nistor, M. M.:
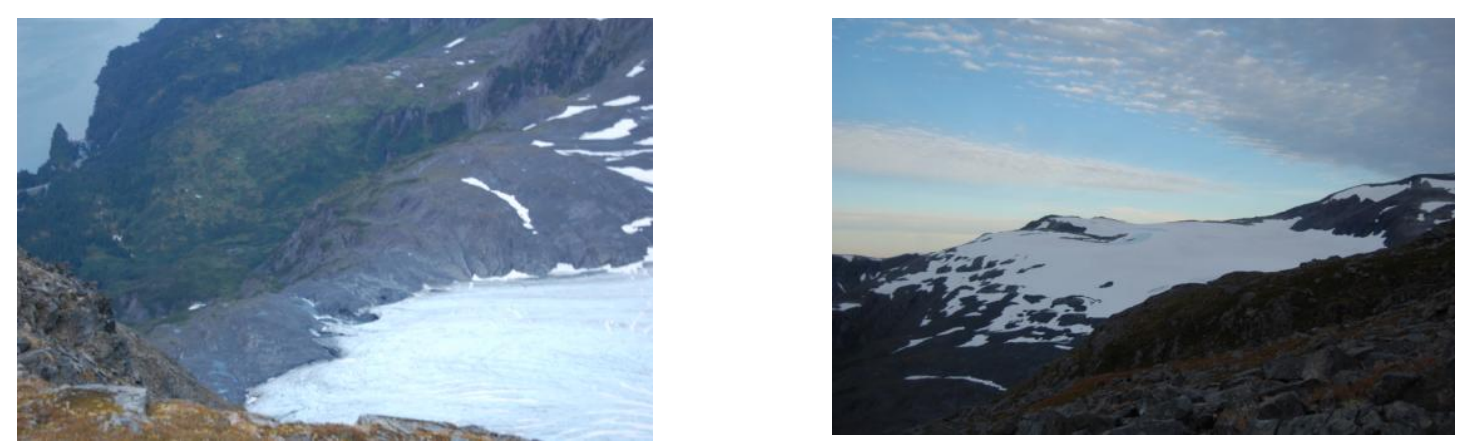

Whittier Glacier terminus in 2010: Northern side (left) and North-Eastern side (right). 

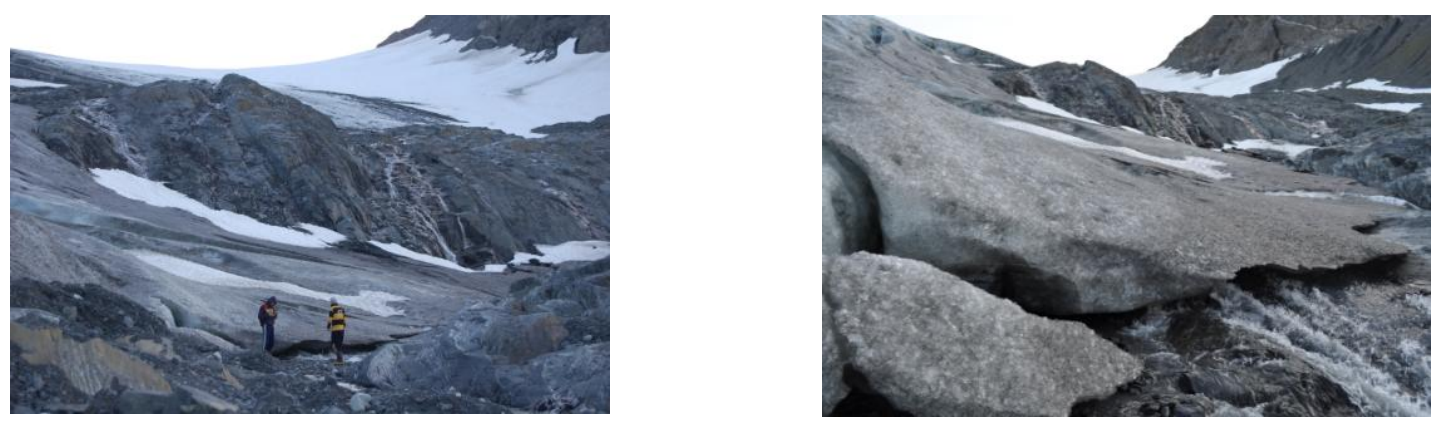

'Moutonnée rochers' and similar landforms presented at terminus of Whittier Glacier (2009 and 2010 years).
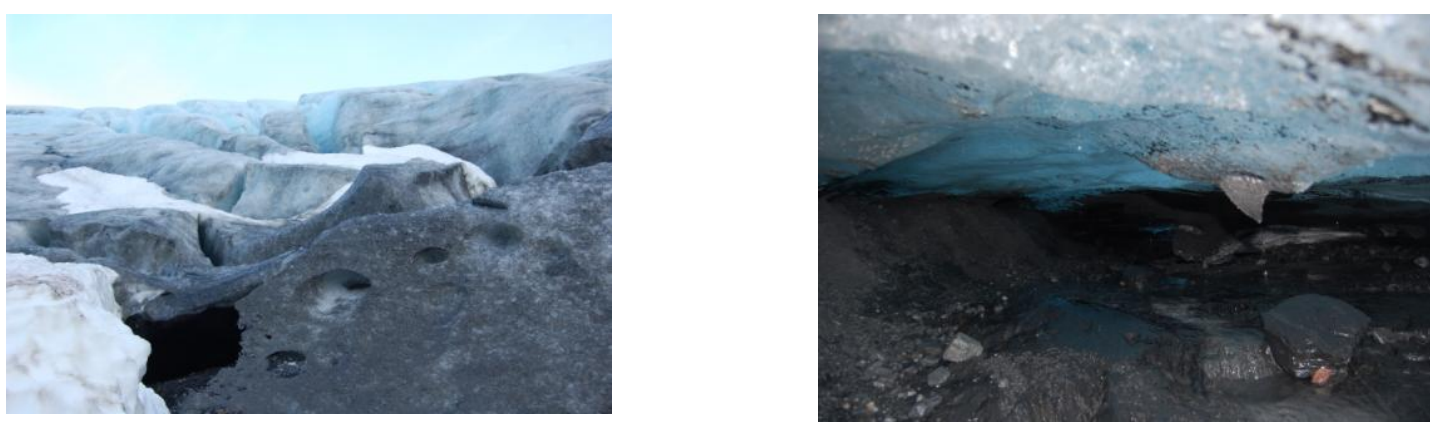

Epi-karst landforms of ice mass formed at terminus of Whittier Glacier (left). Slide bed of Whittier Glacier at terminus (right) (2010).
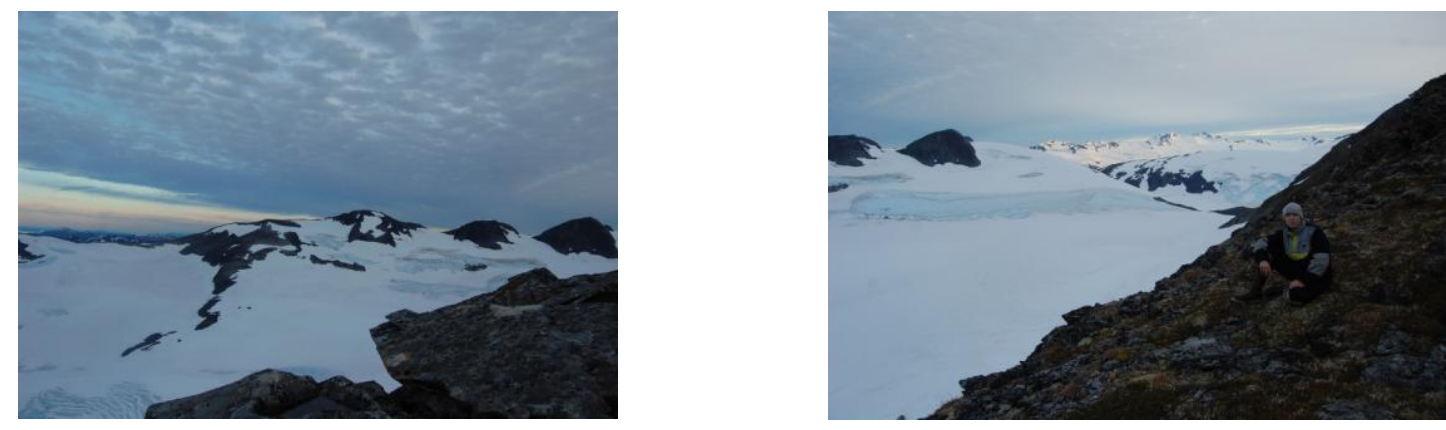

Oblique east-looking ground photograph of Whittier Glacier (left). North-looking ground photograph of Whittier Glacier and the corresponding author picture during field survey (right) (2010). 